\title{
ECTOPIC PREGNANCY: FIVE-YEAR ANALYSIS IN A TERTIARY CARE HOSPITAL OF DELHI
}

\author{
Vinita Sarbhai ${ }^{1}$, Ratnaboli Bhatacharya 2 , Sangita Nangia Ajmani ${ }^{3}$, Mohini Paul $^{4}$
}

${ }^{1}$ Senior Specialist, Department of Obstetrics \& Gynaecology, Kasturba Hospital, Delhi. ${ }^{2}$ GDMO, Department of Obstetrics \& Gynaecology, Kasturba Hospital, Delhi. ${ }^{3}$ Senior Specialist, Department of Obstetrics \& Gynaecology, Kasturba Hospital, Delhi. ${ }^{4}$ Senior Specialist, Department of Obstetrics \& Gynaecology, Kasturba Hospital, Delhi.

\section{ABSTRACT}

\section{OBJECTIVE}

To evaluate the incidence, possible risk factors, clinical presentation, diagnosis and management of Ectopic Pregnancy in a tertiary care hospital.

\section{METHOD}

This retrospective study was conducted at Kasturba Hospital, New Delhi. Data during the period from January 2010 to December 2014 was analysed retrospectively using the case-records and operative notes of patients with suspected ectopic pregnancy.

\section{RESULTS}

There was an incidence of 1.003 ectopic pregnancies per 1000 deliveries. The peak age incidence was 21-30 years (42.3\%) with preponderance in the first and second pregnancies. Past history of abortion and PID were most common high risk factors present in 13.4\% each. Amenorrhea (96.1\%), Vaginal bleeding (73.1\%), Adnexal mass/thickness (73.1\%), and Tenderness on vaginal examination $(73.1 \%$ ) were the commonest presenting features. Isthmo-ampullary was the most common site seen in $67.3 \%$; $52.2 \%$ patients presented with ruptured EP rest $47.8 \%$ presented as un-ruptured. $39 \%$ were given primary medical therapy and out of them $66.6 \%$ responded well. In $74 \%$ surgical treatment had to be given. Salpingectomy was the procedure performed in most cases (58.7\%). Laparoscopic treatment could only be used in 4 patients (8.7\%); 37\% needed blood transfusion.

\section{CONCLUSION}

High index of suspicion, timely early diagnosis and availability of surgical treatment are key to successful management in patients with Ectopic Pregnancy. Medical management in carefully selected cases can play important role fertility preservation.

\section{KEYWORDS}

Ectopic Pregnancy, Risk Factors, Prevalence, Medical and Surgical Management.

HOW TO CITE THIS ARTICLE: Vinita Sarbhai, Ratnaboli Bhatacharya, Sangita Nangia Ajmani, Mohini Paul. "Ectopic Pregnancy: FiveYear Analysis in a Tertiary Care Hospital of Delhi." Journal of Evolution of Medical and Dental Sciences 2015; Vol. 4, Issue 102, December 21; Page:16801-16805, DOI: 10.14260/jemds/2015/2520

\section{INTRODUCTION}

Ectopic Pregnancy (EP) is any pregnancy in which the fertilized ovum implants outside the uterine cavity. More than $95 \%$ of ectopic pregnancies occur in the fallopian tubes. ${ }^{1}$ another $2.5 \%$ occur in the cornu of the uterus and the remainders are found in the ovary, cervix or abdominal cavity. ${ }^{1}$ Ectopic pregnancy continues to be a source of unpreventable fetal wastage and preventable maternal deaths, even in modern day obstetrics. Ectopic pregnancies account for approximately $2 \%$ of reported pregnancies and deaths due to EP account for $9 \%$ of all pregnancy-related deaths. ${ }^{2}$ although the mortality rate is decreasing, the incidence of ectopic pregnancy is increasing and this is thought to be due to increased incidence of salpingitis and better availability of diagnostic modalities. ${ }^{3}$ Delayed treatment due to misdiagnosis leads to half of the deaths. Apart from being a form of reproductive failure, it has a $7-15 \%$ chance of recurrence and only $40-60 \%$ chance of conception after surgery. ${ }^{3}$

Financial or Other, Competing Interest: None.

Submission 03-12-2015, Peer Review 04-12-2015,

Acceptance 15-12-2015, Published 21-12-2015.

Corresponding Author:

Vanita Sarbhai,

C-36, First Floor, Pamposh Enclave,

Greater Kailash,

Part 1, New Delhi.

E-mail: vinitasarbhai@gmail.com

DOI:10.14260/jemds/2015/2520
The occasional maternal deaths and the rising incidence of ectopic pregnancies reinforce the need for understanding and recognizing the clinical manifestations of this condition. This paper reviews the clinical presentation, diagnosis, and management of ectopic pregnancy in Kasturba Hospital, New Delhi, over a period of five years. The objective of this study was to assess the possible risk factors, clinical features, early diagnosis and analyse the various aspects of management of EP with a view to suggest interventions that would decrease the incidence and help in better management option, followup and future fertility concerns.

\section{METHODS}

This is a retrospective study that registered all women with suspected ectopic pregnancy who were admitted in Obstetrics and Gynaecology at Kasturba Hospital, New Delhi, from January 2010 to December 2014. 61women with suspected ectopic pregnancy who presented with amenorrhea, pain, and adnexal mass were included in the group. Data were analysed, using the case sheets and operative notes for age, parity, contraceptive methods, significant past medical and surgical history, clinical presentation, ultrasonography findings, operative findings and outcome of treatment. The incidence of ectopic pregnancy was calculated in reference to number of deliveries during the study period. 


\section{RESULTS}

During this period the number of deliveries in Kasturba Hospital was 51,806 whereas 61 patients were admitted with clinically suspected ectopic pregnancies. Out of these EP was confirmed by further investigations in 52 patients. This makes an incidence of 1.003 per 1000 deliveries. Out of them, 50 $(82 \%)$ women had tubal ectopic pregnancies and one patient each had a cervical (1.65\%) and ovarian pregnancy (1.65\%). Ectopic pregnancy was ruled out by further investigations in 9 patients (14.75\%) and were diagnosed to have Pelvic inflammatory disease (PID) (2), abortion (2), enteric fever (1), appendicular lump (1) early pregnancy with PID (1) and incomplete abortion with PID (1). One patient presented as ovarian ectopic pregnancy but was later diagnosed as Embryonal Cell Carcinoma on histopathology; 6 patients were lost to follow-up as they left against medical advice.

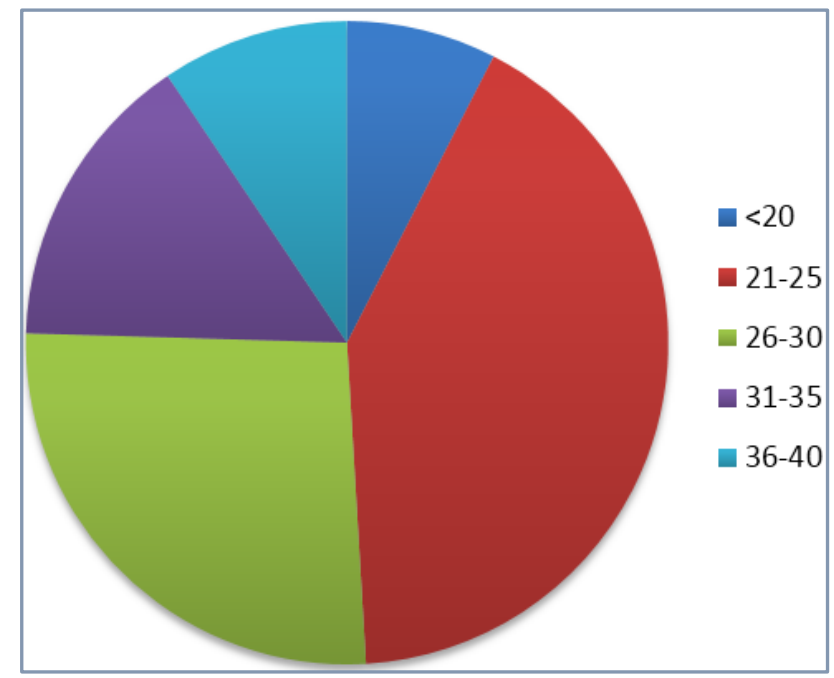

Picture. 1: Distribution of cases according to Age

The peak age incidence was 21-30 years (42.3\%) with preponderance in the first and second pregnancies. This corresponds to the age of reproduction and peak sexual activity. Maximum cases were nulliparous (61.5\%) followed by primipara and second parity.

\begin{tabular}{|c|c|c|}
\hline Predisposing Factors & Number & $\begin{array}{c}\text { Percentage } \\
\text { (\%) }\end{array}$ \\
\hline Previous PID/ TB & 7 & 13.4 \\
\hline H/O Abortion & 7 & 13.4 \\
\hline $\begin{array}{c}\text { Previous surgery } \\
\text { (LSCS/D\&C) }\end{array}$ & 5 & 9.6 \\
\hline Previous tubal surgeries & 2 & 3.8 \\
\hline Endometriosis & 1 & 1.9 \\
\hline Unknown factors & 30 & 57.7 \\
\hline \multicolumn{2}{|c|}{$\begin{array}{c}\text { Table 1: Distribution of cases according } \\
\text { to Predisposing Risk factors (n=52) }\end{array}$}
\end{tabular}

Past history of abortion and previous history of PID and tuberculosis were most common high risk factors present in $13.4 \%$ each and $9.6 \%$ people had history of prior surgical intervention in the form of D and C or Caesarean section; 3.8\% patients had undergone previous tubal surgeries in the form of recanalization or salpingectomy for prior ectopic pregnancies; $1.9 \%$ had endometriotic lesions. In the rest, no risk factors could be elicited.
Presenting Symptoms

\begin{tabular}{|c|c|c|}
\hline Presentation & Number & $\begin{array}{l}\text { Percentage } \\
(\%)\end{array}$ \\
\hline Amenorrhea & 50 & 96.1 \\
\hline Abdominal pain & 28 & 53.8 \\
\hline Abdominal tenderness & 26 & 50.0 \\
\hline Vaginal bleeding & 38 & 73.1 \\
\hline Adnexal mass/thickness & 38 & 73.1 \\
\hline $\begin{array}{l}\text { Tenderness on vaginal } \\
\text { examination }\end{array}$ & 38 & 73.1 \\
\hline Fainting/giddiness & 11 & 21.1 \\
\hline Shock & 4 & 7.7 \\
\hline \multicolumn{3}{|c|}{$\begin{array}{l}\text { Table 2: Distribution of cases according } \\
\text { to Clinical Presentation }(n=52)\end{array}$} \\
\hline
\end{tabular}

Amenorrhea was present in almost all the cases except in two instances where it could not be readily defined; $53.8 \%$ patients presented with abdominal pain, which varied from a dull ache to colic like intermittent pain or the sudden severe stabbing sensation frequently associated with syncope or fainting. However a large share $(73.1 \%)$ of the patients had adnexal tenderness or cervical motion tenderness on vaginal examination. In $73.1 \%$ patients, adnexal mass/thickening/fullness could be elicited on vaginal examination.

Among 46 patients that could be followed up, only 18 (39.1\%) presented in hemo-dynamically unstable condition, i.e. having tachycardia ( $>100 / \mathrm{min})$ and low blood pressure $(<100 / 60)$ including 4 patients who presented in shock. Rests $28(60.9 \%)$ were in hemo-dynamically stable condition. 24 (52.2\%) patients presented with ruptured ectopic pregnancies, whereas only $22(47.8 \%)$ patients presented in un-ruptured condition.

USG (TVS) was done in all but two patients (As they were hemo-dynamically unstable) and findings correlated well with the per-operative findings and clinical diagnosis in all patients except in two cases. Thus, it had $98 \%$ diagnostic accuracy. In one patient, TVS identified only an ovarian cyst whereas preoperatively the patient was found to have ruptured fimbrial end of a tube accompanied by ovarian cyst. The other case was diagnosed as embryonal carcinoma of ovary.

On the basis of USG and surgical findings, most of the patients $35(67.3 \%)$ had isthmo-ampullary ectopic pregnancies, 8 (15.4\%) patients presented as tubal abortion; 6 (11.5\%) patients had fimbrial involvement. There was one patient $(1.92 \%)$ each of ovarian pregnancy, cornual and cervical pregnancy.

\begin{tabular}{|c|c|c|}
\hline Site of Ectopic Pregnancy & Number of Cases & $\mathbf{\%}$ \\
\hline Isthmo-Ampullary & 35 & $67.3 \%$ \\
\hline Tubal abortion & 8 & $15.4 \%$ \\
\hline Fimbrial & 6 & $11.5 \%$ \\
\hline Ovarian & 1 & $1.92 \%$ \\
\hline Cornual & 1 & $1.92 \%$ \\
\hline Cervical & 1 & $1.92 \%$ \\
\hline \multicolumn{2}{|c|}{ Table 3: Distribution of cases } \\
according to site of EP (n=52) \\
\hline
\end{tabular}

\section{MANAGEMENT}

The clinical presentation, ultrasound features, serum $\beta$-hCG level and reproductive history of the patient guided the management. Out of 52, 6 patients left against medical advice, hence management was carried out in 46 patients only. (Table IV, Picture 2). 


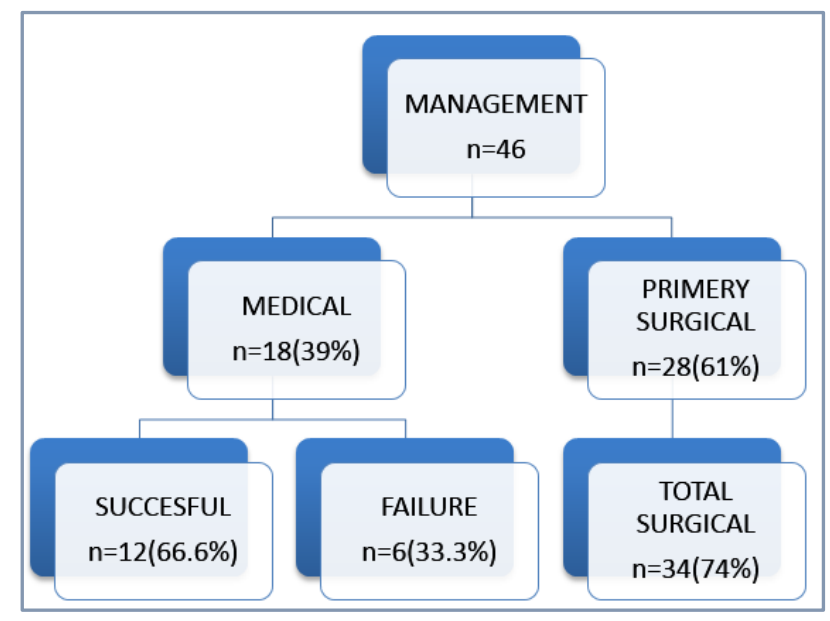

Picture. 2: Distribution of cases according to Management

\begin{tabular}{|c|c|c|}
\hline Management & Cases & $\%$ \\
\hline SURGICAL & 34 & $74 \%$ \\
\hline Salpingectomy & 27 & $58.7 \%$ \\
\hline Salpingo-oophorectomy & 2 & $4.3 \%$ \\
\hline Rent repair at isthmus & 1 & $2.2 \%$ \\
\hline Laparoscopic salpingectomy & 3 & $6.5 \%$ \\
\hline Laparoscopic salpingostomy & 1 & $2.2 \%$ \\
\hline MEDICAL & 12 & $26 \%$ \\
\hline \multicolumn{3}{|c|}{$\begin{array}{c}\text { Table 4: Distribution of cases } \\
\text { according to Treatment modality }(n=46)\end{array}$} \\
\hline
\end{tabular}

\section{MEDICAL MANAGEMENT}

Methotrexate (MTX) was the drug used for conservative medical treatment; $50 \mathrm{mg} / \mathrm{m} 2$ of methotrexate was administered on day 0 (Stovall regimen). ${ }^{4}$ It was monitored by serum $\beta$-hCG level. A fall of $15 \%$ or more between 4 and 7 days then weekly fall until it was lower than $15 \mathrm{mIU} / \mathrm{ml}$ was considered as successful response to therapy. A second dose of MTX was repeated when fall of $\beta$-hCG was less than $15 \% ; 12$ out of 18 patients managed by medical management responded well (66.6\%). Emergency laparotomy was performed in 6 patients due to clinical deterioration; 3 patients needed blood transfusion during surgery in this group.

\section{SURGICAL MANAGEMENT}

In patients who were hemodynamically unstable, had a ruptured ectopic pregnancy or a live fetus, had higher levels of $\beta$-hCG (More than $5000 \mathrm{mIU} / \mathrm{ml}$ ) or a mass more than $3.5 \mathrm{~cm}$ surgical management was preferred. Surgery was performed in 28 out of 46 patients as the first line of management (61\%). In 6 Medical therapy failure patients, surgery was performed as second line of treatment. Salpingectomy was the procedure performed in most cases (58.7\%), as the tubes were nonsalvageable. Ovaries were conserved in all cases except in two patients where in one ovarian pregnancy was suspected and dense tubo-ovarian masses were found in another.

Cervical ectopic was treated by evacuation from below and rent was repaired from above. As laparoscopic treatment was available in last few months of the study, thus it could only be used in 4 patients. Salpingostomy was performed in one of them. (Picture 3) 17 patients needed blood transfusion (37\%)

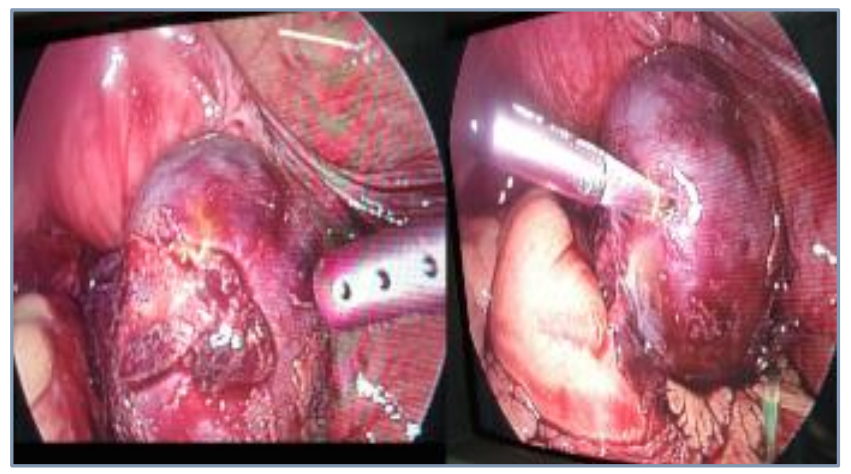

Picture. 3: Un-ruptured Ectopic Pregnancy management by Salpingostomy

\section{DISCUSSION}

Ectopic pregnancy remains one of the leading causes of pregnancy related first trimester maternal morbidity and mortality. In our study the incidence of ectopic pregnancy was 1.003 per 1000 deliveries similar to 2.46 per thousand of deliveries in the study by Porwal Sanjay et al. ${ }^{5}$ This was less than the incidence in western world, (27.2 per thousand reported pregnancy, as per CDC surveillance summary, 1993). ${ }^{2}$ probably because of early presentation and early diagnosis in the west. Women in developing world do not report early pregnancy, due to ignorance and hesitation, unless associated with any problem.

Ectopic pregnancy was present in young women with low parity who are desirous of pregnancy. The peak age incidence in our study was 21-30 years, which is consistent with the findings by Porwal Sanjay, 2012.5 and Isabu, $2014 .{ }^{1}$ This was lower than international studies of 30-40 as reported by F. Kopani, $2010 .^{6}$ due to early age of marriage and child bearing in India.

The predominant risk factors of ectopic pregnancy in our study matched with majority of studies conducted in India. ${ }^{5}$ Pelvic Inflammatory Disease (PID) including tuberculosis, chlamydial and gonorrheal infections are more common predisposing factor in developing countries like ours. While, history of abortion is a more important factor in West, as documented by F. Kopani. ${ }^{6}$ and Isabu et al. ${ }^{1}$ 


\begin{tabular}{|c|c|c|c|c|c|}
\hline STUDY & INCIDENCE & $\begin{array}{l}\text { AGE } \\
\text { PEAK }\end{array}$ & PARITY & SITE & $\begin{array}{c}\text { RISK } \\
\text { FACTOR }\end{array}$ \\
\hline $\begin{array}{l}\text { F. Kopani, } \\
2010 .^{6}\end{array}$ & NA & $30-40$ & NA & Amp-isth & $\begin{array}{c}\text { H/O Abortion } \\
52.6 \% \\
\text { H/O surgery } 27.5 \%\end{array}$ \\
\hline $\begin{array}{l}\text { Porwal Sanjay. }^{5} \\
2012\end{array}$ & $\begin{array}{l}2.6 \text { per } 1000 \\
\text { Delivery. }\end{array}$ & $\begin{array}{l}21-25 \\
47.5 \% \\
\end{array}$ & $\begin{array}{c}\text { Nulliparous } \\
40 \%\end{array}$ & Amp-isth $72.5 \%$ & $\begin{array}{c}\text { PID } \\
47.5 \%\end{array}$ \\
\hline $\begin{array}{c}\text { Haifa Turki, } \\
2013 .^{7} \\
\end{array}$ & $1.14 \%$ & $\begin{array}{l}20-30 \\
60.1 \% \\
\end{array}$ & NA & NA & NA \\
\hline $\begin{array}{l}\text { Isabu, } \\
2014 .{ }^{1}\end{array}$ & $1.16 \%$ & $\begin{array}{l}20-25 \\
40.8 \%\end{array}$ & $\begin{array}{c}\text { Nulliparous } \\
49.3 \%\end{array}$ & $\begin{array}{l}\text { Amp } \\
75 \%\end{array}$ & $\begin{array}{c}\text { PID 75.5\% } \\
\text { H/O Abortion } \\
73.1 \% \% \\
\end{array}$ \\
\hline $\begin{array}{l}\text { MPL Rakhi } \\
2014 .^{8}\end{array}$ & NA & $\begin{array}{c}20-25 \\
68.57 \%\end{array}$ & $\begin{array}{c}\text { Primipara } \\
45.71 \%\end{array}$ & $\begin{array}{l}\text { Amp } \\
74.29 \%\end{array}$ & $\begin{array}{c}\text { H/O Abortion } \\
34.29 \% \\
\text { PID } 24.29 \%\end{array}$ \\
\hline $\begin{array}{c}\text { Raina Aditi } \\
2015 .{ }^{9}\end{array}$ & $\begin{array}{l}16 \text { per } 1000 \\
\text { del. }\end{array}$ & $\begin{array}{l}26-30 \\
42.8 \% \\
\end{array}$ & $\begin{array}{c}\text { Nulliparous } \\
42.8 \%\end{array}$ & $\begin{array}{c}\text { Amp-isth } \\
73.7 \%\end{array}$ & PID 38\% \\
\hline $\begin{array}{l}\text { PRESENT } \\
\text { STUDY }\end{array}$ & $\begin{array}{c}1.003 \text { per } 1000 \\
\text { del. }\end{array}$ & $\begin{array}{l}21-25 \\
42.3 \%\end{array}$ & $\begin{array}{l}\text { Nulliparous } \\
61.5 \%\end{array}$ & $\begin{array}{c}\text { Amp-isth } \\
67.3 \%\end{array}$ & $\begin{array}{c}\text { PID 13.4\% } \\
\text { H/O Abortion } \\
13.4 \%\end{array}$ \\
\hline \multicolumn{6}{|c|}{ Table 5: Profile of women presenting as Ectopic pregnancy } \\
\hline
\end{tabular}

Ultrasonography has been found to be promising in the confirmatory diagnosis of ectopic pregnancy by Ikpeze et al.10 It proved to be a great diagnostic tool in our setup with $98 \%$ accuracy consistent with preoperative findings.

\section{Clinical Presentation}

In our study, $67.2 \%$ patients presented with ruptured ectopic pregnancies whereas only $14.8 \%$ presented in an un-ruptured state; $70.5 \%$ patients were hemodynamically stable while 29.5\% had unstable parameters including four people who presented in shock. Our figures are close to other studies in the developing countries where 70 to $95 \%$ cases were ruptured at presentation..$^{711}$ F. Kopani et al. ${ }^{6}$ reported $71 \%$ ruptured ectopic and 29\% un-ruptured. In our study, most of the patients had isthmo-ampullary ectopic pregnancy (67.3\%), which is consistent with studies from other centres. ${ }^{6-9}$

The hemodynamic parameters depend primarily on the amount and pattern of bleeding.

Blood transfusion was given in $43.5 \%$ of patients in our study, which is much more than Western study like F. Kopani. ${ }^{6}$ who reported blood transfusion in $15.8 \%$. As women in developing countries like ours are more anemic and present late to the treating surgeon. Blood transfusion services are therefore necessary in the management of ectopic pregnancy.

\begin{tabular}{|c|c|c|c|c|}
\hline & $\begin{array}{c}\text { Clinical } \\
\text { Presentation }\end{array}$ & Ruptured & $\begin{array}{c}\text { Surgical } \\
\text { Treatment }\end{array}$ & $\begin{array}{c}\text { Need of Blood } \\
\text { Transfusion }\end{array}$ \\
\hline F. Kopani.6 2010 & $\begin{array}{c}\text { Ameno-81\% } \\
\text { Pain } 90 \%\end{array}$ & $71 \%$ & $74.56 \%$ & $15.8 \%$ \\
\hline $\begin{array}{c}\text { Porwal Sanjay. } \\
2012\end{array}$ & $\begin{array}{c}\text { Ameno-90\% } \\
\text { Bleeding-67.5\% } \\
\text { Pain- 87.5\% }\end{array}$ & NA & $100 \%$ & $100 \%$ \\
\hline $\begin{array}{c}\text { Isabu. }{ }^{2} \\
2014\end{array}$ & $\begin{array}{c}\text { Ameno-100\% } \\
\text { Bleeding-58.1\% } \\
\text { Pain- 82.5\% }\end{array}$ & $72.5 \%$ & $100 \%$ & $67.5 \%$ \\
\hline MPL Rakhi.8 & $\begin{array}{c}\text { Ameno-84.29\% } \\
\text { Bleeding-41.43\% } \\
\text { Pain- 82.5\% }\end{array}$ & $85.71 \%$ & $97.14 \%$ & $85.71 \%$ \\
\hline PRESENT & $\begin{array}{c}\text { Ameno-96.1\% } \\
\text { Bleeding-73.1\% } \\
\text { Pain- } 53.8 \%\end{array}$ & $67.2 \%$ & $74 \%$ & $43.5 \%$ \\
\hline \multicolumn{7}{|c|}{ Table 6: Clinical presentation of women presenting as Ectopic pregnancy } \\
\hline
\end{tabular}

\section{MANAGEMENT}

Medical therapy in carefully selected patients (26\%) was found to be a very effective treatment; $66 \%$ of the 18 cases who were given methotrexate responded well. Rates of medical management are lower than in west as many patients in developing world present late. Bouyer J, et al. ${ }^{12}$ reported that $54.9 \%$ were given conservative therapy, out of which $13 \%$ did not respond to therapy.

Surgery was performed in 28 out of 46 patients as the first line of management (61\%). Laparotomy with appropriate surgery was the treatment of choice for haemo-dynamically compromised patients with ruptured ectopic pregnancies and also in patients who failed to respond to medical therapy. Salpingectomy was the mainstay of surgical treatment performed in $82.86 \%$ of cases by MPL Rakhi et al. ${ }^{8}$

Laparoscopy is very important surgical tool for diagnosis as well as treatment. As operative laparoscopy was available in last few months of the study thus it could only be used in 4 patients. Salpingostomy was performed in one of them. Laparoscopic surgical treatment is the selected method for patients that have stabile haemo-dynamic level but surgeon skills are important influence factors for selection of surgical method. 6

A ruptured ectopic pregnancy is a true medical emergency. It is the leading cause of maternal mortality in the first trimester and accounts for 10 to $15 \%$ of all maternal deaths. ${ }^{2,10-12}$ 
Most maternal deaths due to ectopic pregnancy are the result of a sudden massive hemorrhage before the patient even has the opportunity to receive medical assistance. The closer the point of rupture is to the uterus, such as the isthmic or interstitial portions, the more likely it will be horrendous and the bleeding extensive. Since most patients who have ruptured ectopic pregnancies have visited a physician a few days before the rupture, many deaths might be prevented by establishing the diagnosis of ectopic pregnancy early and by initiating therapy prior to rupture..$^{2}$ Mortality was not reported in our series similar to Udigwe GO, et al. ${ }^{13}$ unlike other studies where mortality rates were about 1.5 to $3.7 \% .^{14,15}$

\section{CONCLUSION}

Ectopic pregnancy remains the leading cause of maternal morbidity and mortality in the first trimester of pregnancy. High index of suspicion should be given to a patient presenting with any of the clinical triad amenorrhea, pain and adnexal mass. Emphasis should be given to early antenatal registration, awareness regarding early warning signs, early diagnosis with use of ultrasound, early correct surgery or medical management as and when applicable.

Medical treatment is effective if ectopic pregnancies present early and are diagnosed timely. Laparotomy is the main surgical procedure performed for late presented and ruptured ectopic pregnancies. Blood transfusion is recommended to prevent patient from exsanguination and hence rendered important in management. Promotion of family planning, early and prompt treatment of pelvic inflammatory disease will help lower the incidence. Efforts should be made toward women's education, improved hospital accessibility and better diagnostic skills.

\section{REFERENCES}

1. Isabu PA, Eifediyi RA, Umelo CC, et al. Trends in ectopic pregnancy in a Nigerian sub-rural teaching hospital. Stand Glob. J Med Sci 2014;1(4):82-90.

2. Goldner TE, Lawson HW, Xia Z, et al. Surveillance for ectopic pregnancy, United States 1970-1989. MMWR Mob Mortal Weekly Rep CDC Surveillance Summary 1993;42(SS-6):73-85.
3. Aboyeji AP. Trends in ectopic pregnancy in Ilorin, Nigeria Nigerian Medical Practitioner 2000;38:4-6, 21-23.

4. Stovall TG, Ling HW. Single dose methotrexate: An expanded clinical trial. Am J Obstet Gynecol 1993;168:1759-65.

5. Porwal Sanjay, Gupta R, Swarnkar M, et al. Incidence, trends and risk factors of ectopic pregnancies in a tertiary care hospital of Rajasthan. Journal of Pharmaceutical and Biomedical Sciences 2012;16:1-3.

6. Fatmir Kopani, Arben Rrugia, Nikita Manoku. Ectopic pregnancy comparison of different treatments. J Prenat Med. 2010 Apr-Jun; 4(2):30-34.

7. H Abdulaziz Al-Turki. Trends in ectopic pregnancies in Eastern Saudi Arabia.

ISRN Obstet Gynecol 2013;97:52-51.

8. MPL Rakhi. Ectopic Pregnancy: A devastating catastrophe Sch. J App Med Sci, 2014;2(3A):903-907.

9. Raina A, Bajpai M. Experience with ectopic pregnancy in a hospital in India. Indian Journal of Applied Research. 2015;5(4):535-537.

10. Ikpeze OC (1991). A critical assessment of the usefulness of abdominal ultrasound in the diagnosis of ectopic pregnancy. Nigerian Journal of Surgical Sciences. Vol 1. Pp 25-27. ISSN 1116-5898.

11. Leroy RW. Ectopic pregnancy: Current clinical trends, a fifteen-year study. Journal of the National Medical Association 1981;73(9):823-33.

12. Bouyer J, Coste J, Fernandez H, et al. Sites of ectopic pregnancy: a 10-year population-based study of 1800 cases. Hum Reprod 2002;17:3224-3230.

13. Udigwe GO, Umeonihu OS, Mbuchu II. Ectopic pregnancy: A 5-year review of cases at Nnamdi Azikiwe University Teaching Hospital (NAUTH) Nnewi. Niger Med J 2010;51(4):160-163.

14. Igbarese GO, Ebeigbe PN, Igbekoyi OF, et al. Ectopic pregnancy-11-year review in a tertiary centre in the Niger Delta. Trop Doct 2005;35:17-57.

15. Andrea A Creanga, Carrie K Shapiro - Mendoza, Connie L Bish, Suzanne Zane, Cynthia J Berg, William M Callaghan. Trends in ectopic pregnancy mortality in the United States: 1980-2007. Obstetrics and Gynecology 2011 April; 117(4):837-843. 